\title{
On two Different Fictional Connotations Between Heterogeneous Natural Languages
}

\author{
Diao Chen \\ College of Electrical Engineering \\ Northwest University for Nationalities \\ Lanzhou, China \\ e-mail: 383895315@qq.com
}

\section{Cai Ning}

College of Electrical Engineering

Northwest University for Nationalities

Lanzhou, China

e-mail: caining91@tsinghua.org.cn

Xue Lin

School of Foreign Studies

Beijing, China

University of Science and Technology Beijing

e-mail: ustbxuelin@163.com

\begin{abstract}
Every language is closely related to its culture. Due to historical events, cultural traditions, religious beliefs, natural environment factors, and other aspects, cultures both in English and Chinese language gives animal words specific and different cultural connotations, forming their own specific animal culture. It is the basic content of the national animal culture for a variety of connotation's attitude of animal words. This paper mainly introduces the difference of the Dragon's and Phoenix's connotations between Chinese and western cultures. Impacted by difference events and cultures, the same imagery will be given different connotations. Combining with the paragraphs mentioned above, it will be clear to see that connotations of "Dragon" and "Phoenix" are influencing different culture backgrounds such as religions, histories, imaginations and so on.
\end{abstract}

Keywords-Phoenix; Connotation; Chinese culture; Western culture; History

\section{INTRODUCTION}

Thinking of linguists on the relationship between language and culture has promoted the linguistic research to become more than through the form of the language itself, but also through the language of a national culture to study from past to future. The thinking of linguists on the relationship between language and culture has promoted the linguistic research from the pure form of study to the language through its national culture from past to the future. As the American linguist Edward Sapir have argued [1-2]: "language does not exist apart from culture, that is, from the socially inherited assemblage of practices and beliefs that determines the texture of our lives."

\author{
Liu Wanzhang* \\ College of Electrical Engineering \\ Northwest University for Nationalities \\ Lanzhou, China \\ e-mail: 453036126@qq.com \\ *Corresponding Author
}

\author{
Tian Changhui \\ School of Foreign Studies \\ University of Science and Technology Beijing \\ Beijing, China \\ e-mail: tian_changhui@aliyun.com
}

There are not only mental differences between human beings and animals, but also the language ability making human beings holding the culture, which never exists among the animals [1-2]. It means that the relations of language and cultural is far more then important. However, human beings give the animal words their connotations as well. Although animals will never hold their own cultures, there are always some meanings for some special animals. Actually, most animals have different meanings in different cultures. Human ethnolinguistics (or cultural linguistics) is an interdisciplinary formed edge of linguistics and cultural anthropology (social anthropology) [1-4]. Its overlapping areas cover "language, thought, culture and their relationship", which is the most dynamic and potential exploration in language research, and it will be applied to this essay to research the differences and connections of animal words between Chinese and western cultures.

The relationship between language, thought and culture is also known as the world view of language in the language of thought history [1-5]. Its origin can be traced back to the classical period of Greece's intellectual activity. In the enlightenment campaign of eighteenth century, German, French and British thinkers set the world view of language problems to more clear. The research on this issue is also developed to experience of science from philosophy. In the twenties of last century, as a result of philosophical anthropology and human Linguistics rising, the world view of language has become a focus of modern linguistic and cultural anthropology. Around this focus, the generalized academic, including linguists, anthropologists and philosophers of language, have 
made unremitting exploration until today, and the academic achievements and the impact of this diffuse in theoretical linguistics, sociolinguistics, psycholinguistics, applied linguistics and many other branch disciplines. Although the academic circles dominated by Western research on the relationship between language, thought and culture fruitfully for a long time, but because of its comprehensive and complex nature of this research field, there are still some theoretical and practical problems disturbing the scholars. As the development and extension of the research, there will be more new problems. However, Ethnolinguistics will be the answer of these questions.

Language is a cultural carrier, different social backgrounds and national cultures have a great effect on the cultural connotations of vocabulary [1-8]. Chinese culture and western culture as two different species of culture system, there exists vast differences in language culture connotations. Every language is closely related to its culture. Due to historical events, cultural traditions, religious beliefs, natural environment factors, and other aspects, cultures both in English and Chinese language give animal words specific and different cultural connotations, forming their own specific animal culture. The cultural differences between China and the West result in the same animal containing different cultural connotations. This paper utilizes the data from a large corpus to analyze the words signifying "Dragon" and "Phoenix" and explores the cultural differences between Chinese and Western and their various connotations.

Animal words reflects the moral institution, national spirit, life attitude, aesthetic ideal and other aspects of the content of the national culture, and reflects the nation's social culture and psychological culture. Therefore, analysis of the differences between Chinese and English animal words connotation is beneficial to understand the difference between social culture and psychological culture between nationalities, and conducive to communicate cross-culturally.

This paper is conducted out of two purposes. The first one is, there are many differences between western culture and Chinese culture. Thus, it is significant to know the differences cultures and histories. The second and the primary one is that we will study the animal words as an example through two different kinds of culture and their histories. The paper intends to make a meticulous and deep try to promote more insight in this specific field.

\section{LOONG AND DRAGON}

Chinese dragon is one of the oldest totems of the Han nationality. In ancient times, the people reverenced for nature and worship the magic power, so they created such an idol that can summon wind and call for rain with boundless supernatural power. People knelt to it and pray for peace. Chinese dragon is still mysterious but sacred for thousands years. With regard to the appearance of Chinese dragon, there are many tones around the land, but the ordinary thought is that Chinese dragon is a kind of species with four short legs, slim body like snake, sharp eagle claws with five toes each. Li, Shi-Zhen pointed out in his work Pen-tsao Kan-mu [9]; Compendium of Materia Medica that "Chinese dragon has nine similarities: camel's head, deer's horns, turtle's eyes, cow's ears, snake's neck, mirage's belly, fish's scales, eagle's claws and tiger's palms".

In China, the concept of "dragon" has undergone four stages of evolution process [10], which are 1) Totem worship 2) Divinity worship 3) Combination of dragon god worship and emperor worship 4) Combination of worship for Chinese dragon and Indian dragon.

As the first stage, during the primitive times, some tribes took dragon as their totem and the token for their tribes and ancestors. According to the documentary records, the dragon as a totem was transformed from snake, being originally the totem of the $\mathrm{Fu}-\mathrm{Xi}$ tribe.

In the second stage, as the agriculture and stock raising appeared, the religions were also developed. The simple worship of totem evolved into polytheism. Accordingly, the totem worship of dragon evolved into the worship for dragon gods. People began to deify the dragon and regarded it as the god of water and the god of rainbow.

After the dragon was deified, the worship for it was also combined with the worship for the emperor. During the Qin and Han dynasties, the whole China was unified and it demanded a superior god to integrate the different religions from different lands. Thus, the worship for dragon and emperor was combined. From then on, the emperors of ancient China claimed that they themselves were the embodiments of dragons. They thereby received belief and support from the people by borrowing power from the dragons. Meanwhile, dragon also won a more honorable and noble reputation.

In the fourth stage, the image of Chinese dragon was affected by the dragon from India. During the Sui and Tang dynasty, Buddhism propagated in China very rapidly. The Indian dragon king was also propagated. Actually in the local Chinese culture, there were only dragon gods, but without dragon kings. The term "dragon king" was introduced after Buddhism. Along with it, concepts such as "dragon palaces" and "dragon princesses" also became popular.

After all, there should be a fifth stage, which is the current epoch we are living in. Nowadays, to tell the truth, the belief and worship for dragons have not yet vanished at all although modern science has highly developed. There have been rumors about a dragon body fallen from the sky to the fields of Ying-Kou city in the 30 s of last century. Many people are still keeping on believe Buddhism and trusting that real dragons must exist and the reason why they cannot be seen is that they live in some parallel world.

Chinese dragon is often used to represent a symbol of auspicious. As a kind of sacred fetish created by the ancient Chinese people via combining various powerful animals and natural phenomena, the essence of Chinese dragon is an embodiment of the worship to the natural powers. It is generally accepted that Chinese dragon is a totem of the Chinese nationalities and a token of inheritance of the historical tradition.

It is worth mentioning here that the image of Chinese dragon also deeply impacts other Asian countries, such as Japan and Vienam. Japanese dragon myths amalgamate native legends with imported stories about 
dragons from China, Korea and India. Like these other Asian dragons, most Japanese ones are water deities associated with rainfall and bodies of water, and are typically depicted as large, wingless, serpentine creatures with clawed feet.

Vietnamese dragons (rồng or long) are symbolic creatures in the folklore and mythology of Vietnam. According to an ancient creation myth, the Vietnamese people are descended from a dragon and a fairy. To Vietnamese people, the dragon brings rain, essential for agriculture. It represents the emperor, the prosperity and power of the nation. Like the Chinese dragon, the Vietnamese dragon is the symbol of yang, representing the universe, life, existence, and growth. Extant references to the Vietnamese Dragon are rare now, due to the fierce changes in history that accompanied the sinicization of the Nguyễn Dynasty.

Chinese dragon is an auspicious omen; however, western dragon indicates the disaster. Western dragon, with a pair of huge wings, is absolutely different from Chinese dragon. It is more like a kind of dinosaur, not a snake. Even worse, some of them are joined by crocodiles, lizards, toads and bats, so disgusting! Western dragon can spit fire, which is opposed to Chinese dragon that can control the rain. Western dragon was mentioned in Bible of Revelation the twelfth chapter verse three and verse four: "And there appeared another wonder in heaven; and behold a great red dragon, having seven heads and ten horns, and seven crowns upon his heads. And there was seen another sign in heaven; a great red dragon, having seven heads and ten horns, and on his heads seven crowns." "And his tail drew the third part of the stars of heaven, and did cast them to the earth: and the dragon stood before the woman who was ready to be delivered, for to devour her child as soon as it was born. And his tail was pulling a third part of the stars of heaven down to the earth, and the dragon took his place before the woman who was about to give birth, so that when the birth had taken place he might put an end to her child." In verse nine: "And the great dragon was cast out, that old serpent, called the Devil, and Satan, which deceived the whole world: he was cast out into the earth, and his angels were cast out with him." Therefore, in the "Revelation", the image of the dragon is evil and the incarnation of Satan. The image also runs through the various Christian doctrine and derivative works of literature, art and culture. This evil image has become a typical representative of the western dragon.

According to the above, the authors think that these two kinds of dragon are not the same species. Compared with the name, Chinese dragon, Loong is more acceptable.

\section{FENGHUANG AND PHOENIX}

Feng- Huang is another mythical animal of China, and it has same position with the Loong. Feng- Huang is the none of the species in general. Feng is the male bird, and Huang is the female one. According to the " $\mathrm{Er} \mathrm{Ya}$ release birds" noted by Guo, $\mathrm{Pu}$, Feng- Huang is a kind of mythical animal with "chicken's head, swallow's chin, snake's neck, turtle's back, fish's tail", which is colorful over the body. Chinese people like the word "Prosperity brought by Loong and Fenghuang (Long-Feng-ChengXiang)". One of them is the king of beasts, and the other one is the lord of birds. One is upright and dignified, and the other is elegant and pretty. Their godship is complementary, so the word means that the thing goes to be complete.

But at the present age, when we mention Feng-Huang in Chinese, we are able to associate an idiom: The Phoenix of the nirvana, reborn from the ashes (FengHuang-Nie-Pan, Yu-Huo-Chong-Sheng). But FengHuang is god birds, living in myth. The bird will never die, how to reborn? The key of problem is that FengHuang and phoenix is not the same one. There is a fairy tales in Arabian country: "There was a god bird called Phoenix, dead at the age of five hundred years. It collected woods and burnt if self, and reborn from the ashes, beautifully."

The phoenix of west has the connotation of getting rid of the shackles and breaking oneself, but Chinese Feng-Huang is nobler that emphasizes delivering all living creatures from torment and setting up a perfect example. One is for himself, and the other is for the society. Two kinds of culture are hardly created the same god in ancient time without any intersection, after all.

\section{THE REASON WHY "DRAGON" AND "PHOENIX" CAUSES DIFFERENCES IN CHINESE AND WESTERN CULTURE}

Human beings have been living on the earth over ten thousand years with other animals accompanying. Some special animals are in close relationship with human beings, and help people fight against nature or attack of other animals in the low productivity time. Some of them are gentle and harmless, bring us happiness and eliminate the loneliness.

Traditionally, Chinese prefer feeding dogs to watch the door, feeding cats to catch mice, but it is totally different in western culture. They see their pets as friends without any function.

Hunting culture, represented by the United Kingdom, is European aristocrats' entertainment most time. In early modern Europe, hunting is not for living, but a kind of communication, or an approach of showing their power and skill. Deer, boars, rabbits, and even lion are all hunters' targets. Although hunting is forbidden in many areas, there is also space for hunting in Europeans' mind. And there also have other reasons; the same animal word would be definitely different because of history, function, position and religion. Language and culture have evolved with the development of history. Some significant events or the formation of some kind of cultures have a profound impact on animal words, some of which will provide a connotation for a nonexistent animal.

\section{CONCLUSIONS}

Culture is a way for human to adapt to the nature. Rich and colorful culture is a production of human creating in adaption to the environment. Environment makes animal types different from each other. Living in long life in different environmental and ecological environment, different people giving animal words 
cultural characteristics were also significant. In short, there are various differences between Chinese and English animal culture, which reflects the characteristics of ethnic Chinese and English in thinking, aesthetic concepts and differences in history and culture, which is conducive to understanding intercultural communication. Animal words constitute a large number of idioms and proverbs, and we cannot list all, but it is enough to see the profound of two kinds of animal culture. As long as we usually learn to pay attention carefully and accumulate slowly, we will find it is not only interesting, but also contains rich life philosophy. So understanding the plain and simple animal vocabulary usage will play an important role for us both in English reading and in understanding cultural differences!

\section{ACKNOWLEDGMENT}

This work is supported by the Fundamental Research Funds for the Central Universities of China for Northwest University for Nationalities (Grant No. 31920150007), the Zhejiang Open Foundation of the Most Important Subjects Program, the Project for Young Talents of State Ethnic Affairs Commission (SEAC) of China (Grant [2013] 231), and by National Natural Science Foundation (NNSF) of China (Grants 61263002 \& 61374054).

The authors would like to express thanks to Prof. M. J. Khan with the School of PN Engineering, National
University of Sciences and Technology, Islamabad, Pakistan and Prof. J. Cao with the Research Institute of Information Technology, Tsinghua University, Beijing, China for their beneficial discussions about this interesting topic.

\section{REFERENCES}

[1] Edward Sapir. Language-an Introduction to the Study of Speech New York: Harcourt, Brace and company, 1921.

[2] Edward Sapir, "Culture, Genuine and Spurious," The American Journal of Sociology, vol. 29, pp. 401-429, 1924.

[3] Claire Kramsch. Language and culture. Shang Hai Foreign Language Education Press, 2000.

[4] Eugene A. Nida. Language and culture: contexts in translating. Shang Hai Foreign Language Education Press, 2001.

[5] David L. Shaul, N. Louanna Furbee. Language and culture. Waveland Pr Inc, 1997.

[6] Lilian P. Carswell. Telling the Truth about Animals: Epistemology, Ethics, and Animal Minds in Melville, Darwin, Saunders, and London. Columbia University, 2004.

[7] Huang Kun, "Comparative Study Between Chinese and Western Culture in Kung Fu Panda 2," Studies in Literature and Language, vol. 6, pp. 70-73, 2013.

[8] Xue, L. The comparison between traditional Chinese literacy strategies and English vocabulary strategies, Sino-US English Teaching, vol. 1, pp. 42-45, 2009.

[9] Shi-Zhen Li, Compendium of Materia Medica, People's Medical Publishing House, 1963. (In Chinese)

[10] Xing-Liang He, "Significan transition and evolution stages of Chinese culture of dragon", China Art, vol. 859, 2012. 